\title{
OLTÓVÍZ FELFOGÓ ÉS TÁROLÓ LÉTESÍTMÉNYEK TERVEZÉSE ÉS LÉTESÍTÉSE NÉMET ÚTMUTATÓ ALAPJÁN
}

\section{PLANNING AND ESTABLISHMENT OF FIRE-WATER RETENTION AND STORAGE FACILITIES BASED ON GERMAN GUIDELINES}

\author{
BÍRÓ Tibor; HOFFMANN Imre; KÁTAI-URBÁN Maxim \\ (ORCID: 0000-0002-5553-9850) (ORCID: 0000-0002-8886-3446) \\ (ORCID: 0000-0001-5079-4644) \\ biro.tibor@uni-nke.hu; imre.hoffmann@bm.gov.hu; \\ maxim.katai-urban@katved.gov.hu
}

\begin{abstract}
Absztrakt
A veszélyes üzemekben esetlegesen bekövetkező veszélyes anyaggal kapcsolatos súlyos balesetek a tüzoltásnál keletkezett szennyezett oltóvíz által a felszíni- és felszín alatti vizekbe, vagy a talajba kerülve jelentős környezeti károkat okozhatnak.

Jelen cikkben a szerzők célja elemezni és értékelni a nemzetközi szabályozás elóirásainak megfelelö oltóvíz felfogó és tároló létesitmények tervezéséhez és létesitéséhez Németországban használt müszaki útmutató alkalmazhatóságát.
\end{abstract}

Kulcsszavak: ipari balesetek; oltóvíz felfogás; katasztrófavédelem, környezetszennyezés, következmények felszámolása

\begin{abstract}
The industrial accidents involving dangerous substances occurred at dangerous establishments as a result of the generated contaminated fire-water can cause major environment consequences to the surface and ground waters.

The authors of this article in compliance with international regulation will analyse and assess the applicability of the German technical guidelines used for the planning and establishment of fire-water retention and storage facilities
\end{abstract}

Keywords: industrial accidents; fire-water retention; disaster management, environment pollutions, elimination of consequences 


\section{BEVEZETÉS}

A veszélyes anyagokkal kapcsolatos súlyos balesetek (a továbbiakban: súlyos balesetek) az emberi egészséget és a környezetet veszélyeztetik. A rövidtávú emberi egészséget veszélyeztető hősugárzási, robbanási és mérgező hatásokkal részletesen foglalkozik a nemzetközi és hazai szakirodalom. A környezeti hatások alatt a kibocsátó forrás általi környezetveszélyeztetést értjük elsősorban.

A súlyos balesetek környezeti hatása - a szállító közeg szempontjából - lehet légnemü levegőben és folyékony halmazállapotban vízben terjedő jellegü. Az utóbbi a talajba szivárogva az ivóvízbázist is veszélyeztetve a környezetre érzékeny környezeti elemekben hosszútávú, többségében vissza nem fordítható és gyakran az ember költségigényes beavatkozása nélkül helyre nem állítható hatásokat okozhat. [1]

A veszélyes tevékenységekben (veszélyes üzemekben) esetlegesen bekövetkező veszélyes anyag kibocsátásával járó súlyos balesetek és tüzesetek következtében a szennyezett oltóvíz a felszíni- és felszín alatti vizekbe, vagy a talajba kerülve jelentős környezetkárosodást okozhat.

1986-ban a svájci Bázelben lévő Sandos növényvédőszer raktárban bekövetkezett tüzeset által 30 tonna veszélyes anyag került a Rajna folyamba, amelynek 70 kilométer hosszú szennyezési csóvája országhatáron túli szennyezést okozott Németországban, Franciaországban és Hollandiában, mintegy 700 folyamkilométer hosszúságban. [1]
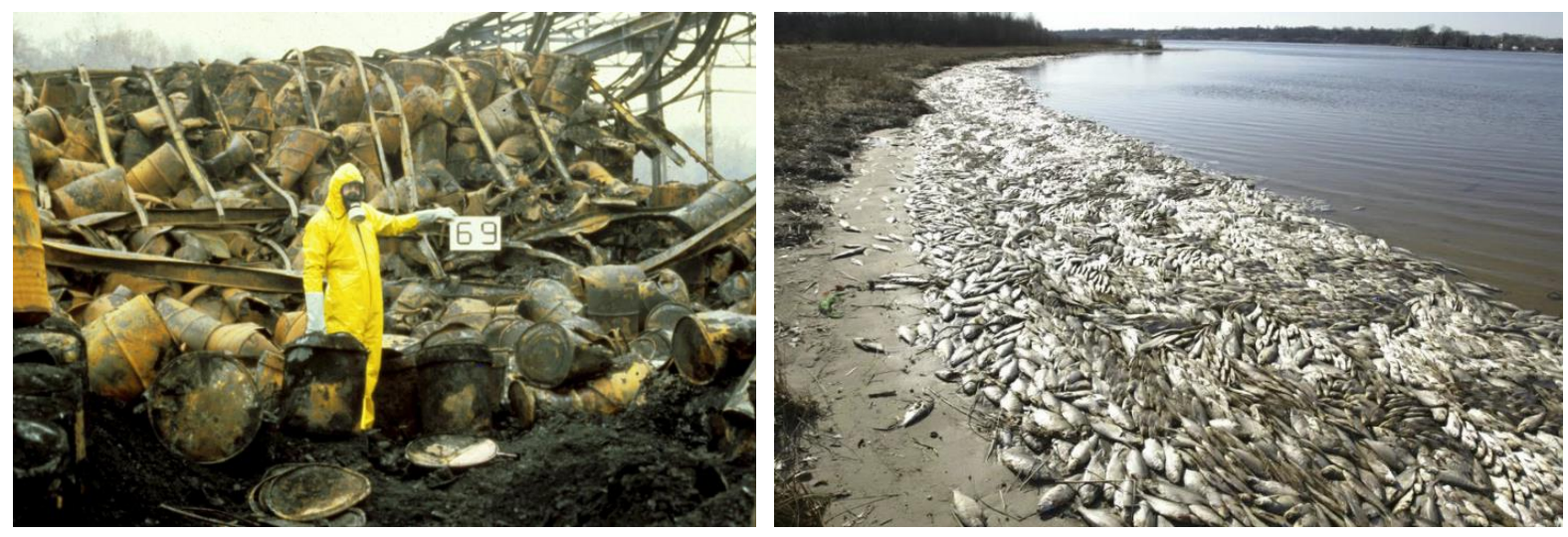

1. fénykép: Sandosi baleset, 1986. Bázel Svájc [2]

A Sandozi baleset példáján érzékelhető, hogy az oltóvízzel történő baleseti vízszennyezésnek lehetnek akár katasztrofális országhatáron túli hatásai is, ezért a hasonló balesetek idején keletkező oltóvíz felfogása útján történő megelőzése a nemzetközi szervezetek feladata lett. [3] Az ENSZ EGB Ipari Baleseti Egyezmény [4] és Határvízi Egyezmény [5] Közös Szakértői Munkacsoportjának (Joint Expert Group, JEG) égisze alatt a fentiekben azonosított konkrét szabályozási feladat céljaira létrehozott Szakértői Munkacsoport kidolgozta „a Biztonsági Irányelvek és Jó Gyakorlat az oltóviz kezelése és felfogása” címü módszertani útmutatót (a továbbiakban: ENSZ EGB útmutató). [6]

Az Európai Unió területén a súlyos balesetekkel kapcsolatos nemzetközi szabályozás az ún. Seveso III. Irányelv [7] elöírásaiban jelenik meg, amely a veszélyes anyaggal foglalkozó üzemeltetők részére ír elő megelőzési, felkészülési és balesetelhárítási intézkedéseket. [8]

A Seveso III. Irányelv II. mellékletében határozza meg a biztonsági jelentés tartalmi követelményeit, amelyek között az 5. pontban nevesíti „, a súlyos baleset következményeinek korlátozása érdekében bevezetendö védelmi és beavatkozási intézkedéseket”. A tartalmi követelményeket megadó felsorolásban pedig a következőket találhatjuk: „A súlyos balesetek emberi egészséget és környezetet érintö következményeinek korlátozását szolgáló berendezések, mint például .... a veszélyhelyzeti felfogó-edények, ....... az oltóvíz felfogók." 
A nemzetközi és EU jogi szabályozás végrehajtására oltóvíz felfogás területén többféle üzemeltetői használatú útmutató alkalmazása ajánlott, amelyek közül kiemelkedő fontosságú a Németországban, 2013-évben a Német Biztosítók Szövetsége által kiadott VdS 2557. számú az „oltóvíz felfogó létesitmények tervezéséről és kivitelezéséről szóló útmutató” [9] (a továbbiakban: útmutató).

Jelen cikkben a szerzők az oltóvíz felfogásához alkalmazott létesítmények tervezését és kivitelezését szabályozó német útmutató veszély- és kockázatelemzésre, az oltóvíz mennyiség becslésére, a szennyezés megelőzésére és a felfogó létesítményekre vonatkozó előírásainak alkalmazhatóságát vizsgálják meg.

\section{A VESZÉLY- ÉS KOCKÁZATELEMZÉSRE ÉS A SZENNYEZETT OLTÓVÍZ MENNYISÉGÉNEK BECSLÉSÉRE VONATKOZÓ ELÖÍRÁSOK BEMUTATÁSA}

Az útmutató alapján a szennyezett oltóvíz okozta károk elkerülését célzó intézkedések bevezetése minden esetben kötelező, ha veszélyes mennyiségü káros anyag kerülhet az oltóvízzel együtt tűz esetén a környezetbe. A veszély- és kockázatelemzés eredményeként kapjuk meg az intézkedések szükségességét, valamint fajtáját és mértékét is.

A veszélyes anyag kockázatának mértékével kapcsolatosan az útmutató többek között a következő anyagokkal foglalkozik:

- a víz veszélyeztetési kategóriákba (WGK) besorolt vízre veszélyes anyagok;

- olyan vízre veszélyes anyagok, amelyeket ez idáig nem soroltak be, de veszélyes jellemzőik miatt besorolhatnak (korábban: "R" kifejezések; jelenleg: a GHS "P" kifejezések szerint);

- élelmiszerek, amelyekre a meghatározás szerint nem lehet WGK besorolást kiadni;

- termelési anyagok (nyersanyag és fogyó anyagok, közbenső termékek, félkész és késztermékek, csomagolási, tárolási és szállítási segédanyagok, hulladék) amelyek maguk, illetve amelyeknek az égéstermékei veszélyes jellemzőket mutatnak;

- építési anyagok (szigetelő anyag, tömítő anyag, impregnáló anyag, amelyek maguk, illetve amelyeknek az égéstermékei veszélyes jellemzőket mutatnak;

- tüzoltó anyag. [9]

A szennyezett oltóvíz által okozott lehetséges veszélyeztetés ellenőrzésére és - amennyiben ilyen előfordul - a szükséges megelőző intézkedések megtételéhez veszély- és kockázatelemzést kell készíteni, amely felöleli a tüzeset idején és azt követően kibocsátott szennyezett oltóvíz lehetséges mennyiségének megállapítását is. Az oltóvíz szennyezés kialakulhat az üzemben lévő építési anyagok, termelési anyagok, csomagoló anyagok hatásai miatt is. Az éghető anyagok kockázati potenciáljának megállapításánál figyelembe lehet venni olyanokat is, amelyeket nem minősítettek veszélyes anyagnak, vagy amelyeket nem lehet veszélyesnek minősíteni, de ennek ellenére veszélyes jellemzőket mutatnak tüz esetén.

A veszély- és kockázatelemzés első lépése az anyag ún. kockázati potenciáljának meghatározása. A veszély- és kockázatelemzésen belül először is azonosítani kell az anyagokat egy esetleges tűz utáni oltóvíz szennyezés szempontjából. A lehetséges égéstermékek megállapításához elégendő minőségi elemzést készíteni.

Itt tekintetbe kell venni, hogy egy tủz olyan égéstermékeket képezhet, amelyek az oltóvíz további szennyezését okozhatják, mint például PVC égése (sósavgázt szabadít fel, sósav képződik) és/vagy tüzoltás szintetikus anyagok, gumiabroncsok, vagy gyúlékony folyadékok égése esetén vizet veszélyeztető habképző vegyületekkel (például fluorozott felületaktív anyagok).

Arról is említést kell tennünk, hogy milyen szennyező anyagokat használnak például termelési anyagként, mit használnak oltóanyagként, és/vagy milyen szennyező anyagok képződhetnek tűz esetén, amelyek emiatt az oltóvíz szennyeződéséhez vezethetnek. Számításba 
kell venni a termelési anyagokat (alapanyagok, közbenső termékek, félkész és késztermékek, tárolt, biztosított és a termeléshez rendelkezésre álló anyagok, hulladékok), a csomagolási, tárolási és szállítási segédanyagokat, az épületszerkezeti anyagokat (szigetelő anyag, tömítő anyag, impregnáló anyag), a tüzoltó anyagot, a höre lebomló anyagokat, amelyek a oltóvizet szennyező pirolízis égéstermékeket képezhetnek. A veszélyazonosítás során a veszélyes anyagok jellemzőit kell meghatározni az ún. WGK besorolás (biztonsági adatlap segítségével a GHS szerint: H figyelmezető mondatok) alapján.

A következő lépés az égési jellemzők meghatározása, amelyhez használt kritériumok az alábbiak: az éghető folyadékok lobbanáspontja; a szilárd anyagok fütőértéke és égési sebessége; valamint a tüzterhelés. A raktárkészletek nyilvántartása folyamatosan változik, ezért az égési jellemzőket időközönként felül kell vizsgálni, vagy készlet szoftverrel nyilvántartani.

A fentieken túl az útmutató elöírja a következő körülmények figyelembe vételét is: a vállalat környezete (védett vízterület; ökológiai rendszer); tüzoltó anyag (habképző anyag); lefolyócsatorna rendszer (a víztisztító üzem / lefolyó csatorna mérete, típusa); tüzvédelmi infrastruktúra (létesítményi tüzoltóság, önkéntes tüzoltók, beépített tüzoltó rendszerek, tüzjelző rendszer); az oltóvíz felfogás szerkezeti követelményei (például alagsor, fogadóterek, szennyvíz rendszerek/vezetékek kiépítésének formája). [9]

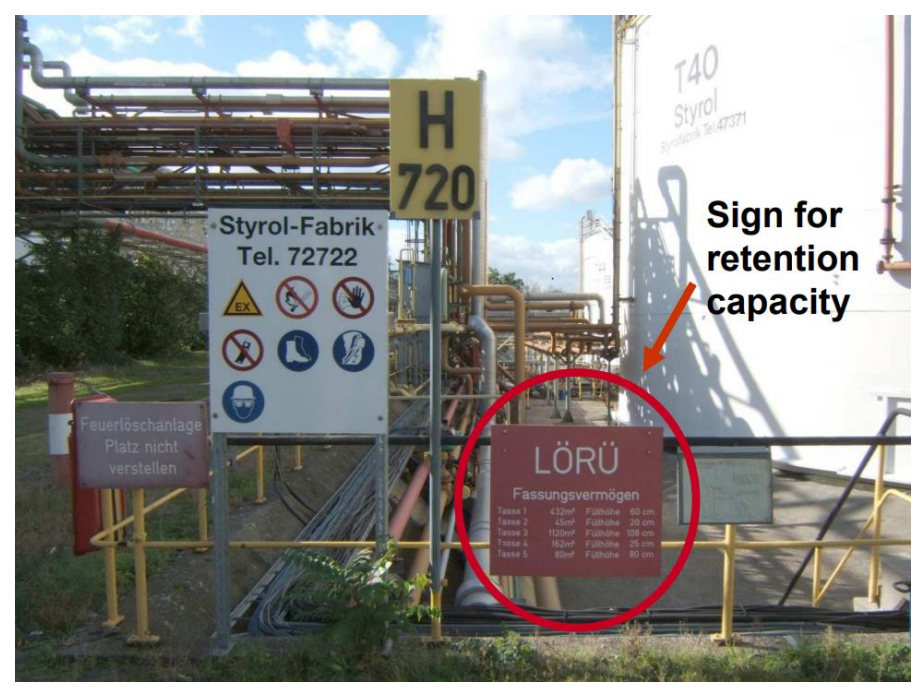

2. fénykép: oltóvíz felfogó tároló létesítmény [10]

A szennyezett oltóvíz mennyisége többek között függ az éghető anyagok fajtájától és mennyiségétől, a tüz érzékelés módszerétől, a tüzoltóság típusától, valamint a tüzvédelmi infrastruktúrától.

Az útmutató meghatározása alapján az oltóvíz veszélyes anyagokkal vagy egy tủz során keletkező veszélyes anyagokkal történő veszélyeztetésének nincs közvetlen hatása a felhasznált szennyezett oltóvíz mennyiségére, azonban ezek a szempontok a tüzszakaszok méretére és az oltóvíz felfogásához szükséges intézkedésekre hatással lehetnek.

Az útmutató szerint egy közepes méretű ipari tüzhöz szükséges oltóvíz mennyisége 3,200 és 14,000 liter/perc között van. Az ilyen nagyságú tüzesetek során ennek következtében 194-840 köbméter oltóvíz keletkezhet óránként, és ez rendszerint 2-4 óráig tart. A felhasznált oltóvíznek körülbelül a fele elpárolog. Az oltóvíz mennyiség számításához egy bonyolult képlet, a tényezők meghatározására táblázatokat használ az útmutató. Az eljárás alkalmazásához a www.vds.de internetes honlapon egy számítási ürlap áll az alkalmazók rendelkezésére. Amennyiben a számítás eredményeként több mint $1000 \mathrm{~m}^{3}$ oltóvíz mennyiség adódik, akkor ajánlatos megfontolni a tüzszakasz területek korlátozását, valamint beépített tüzoltó rendszerek létesítését. 


\section{A SZENNYEZETT OLTÓVíZ ÁLTAL OKOZOTT HATÁSOK MEGELŐZÉSÉRE ÉS KEZELÉSÉRE SZOLGÁLÓ INTÉZKEDÉSEK ÉS ESZKÖZÖK ÁTTEKINTÉSE}

Az oltóvíz felfogásának szükségességét és a szükséges oltóvíz mennyiséget a következő tényezők határozzák meg:

- Egyenlő tárolási sürüség esetén a kis tüzszakaszok elválasztása, illetve a veszélyes anyagok tüzálló szerkezeti elemekkel történő szétválasztása az oltóvíz mennyiségének csökkenését eredményezi.

- A nem éghető építőanyagok használata csökkenti a tüzterhelést és a tüz terjedését az épületben, és ennek következtében a szükséges oltóvíz mennyiségét.

- A tüzveszélyes gáz érzékelő és tüzjelző rendszer telepítése, és ennek hatására egy tüz korai észlelése pozitív hatású a tűz kiterjedésére és terjedésére, és ezáltal a szükséges oltóvíz mennyiségére.

- Az automatikus vízzel oltó rendszerek segítségével eloltható a tüz, és terjedése már a legelső kialakulási fázisában leállítható, még mielőtt kiérkezne a tüzoltóság. Ekkor a tüzoltóság által használandó oltóvíz szükséges mennyisége kevesebb, mint egy kiterjedt tüz esetén tüzoltó rendszer nélkül.

- Ha gáz vagy por alapú tüzoltó anyaggal müködő tüzoltó rendszert használnak, illetve állandó semlegesítő rendszer esetén szinte teljesen kizárható, hogy oltóvízre legyen szükség,

- Speciális tüzoltó anyagok használata (például habképző vegyület vagy fluorozott filmképző anyagok) szennyezett oltóvizet képezhet. [9]

A szennyezett oltóvíz által okozott károkat meg lehet előzni szervezési és müszaki intézkedések bevezetésével, valamint müszaki berendezések telepítésével.

Elsőként ellenőrizni kell, hogy a szervezési (irányítási) intézkedések elegendők-e. Ilyen intézkedések lehetnek a következők:

- Ellenőrizni kell a veszélyes üzem és az ivóvízbázis közötti távolságot.

- Fel kell vázolni a csatornarendszer tervét.

- Ellenőrizni kell, hogy a csatornarendszer kombinált vagy elkülönített szennyvízrendszer.

- Ellenőrizni kell a csatornarendszer oltóvíz felfogására való alkalmasságát és víztömörségét.

- Ellenőrizni szükséges a vállalati szennyvíztisztító üzemet, hogy alkalmas-e a szennyezett oltóvíz tisztítására, ahol figyelemmel kell lenni a káresemény miatti meghibásodás kockázatára is.

- A víz elvezetési módjának ellenőrzése: közvetlen elvezetés felszíni vizekbe, elvezetés víztisztító üzembe, esővíz túlfolyó tartály megléte a fó vagy másodlagos vezetékben.

- Rendszeresen ellenőrizni szükséges az elzáró szerelvények állapotát és működését;

- A dolgozók és külső személyzet (különösen a beszállítók, az alvállalkozók, a szolgáltatók, stb.) veszélyhelyzeti tájékoztatása a biztonsági óvintézkedésekről tájékoztató kiadvány, oktatás és gyakorlatok alkalmazásával.

- Annak ellenőrzése, hogy az eszközök/szerkezetek felszerelése/ telepítése/ beépítése alkalmas-e oltóvíz felfogására (lejtős területek, mélyebb üzemi területek, küszöbök, stb.).

- Kárelhárítási (lokalizációs) intézkedési terv készítése az illetékes tüzoltósággal együttmüködve.

- Terv készítése az oltóvíz felfogására, megadva annak helyét, típusát és mennyiségét.

- A mobil gátak és kárelhárítási berendezések telepítését erre felkészített dolgozókkal rendszerint telephelyen belül kell elvégezni. 
- A veszélyhelyzeti intézkedések dokumentálása fontos feladat. A riasztási eljárások meghatározása (illetékes hatóságok, mentő szervezetek, és a veszélyes üzem felelős személyei).

- Veszélyhelyzeti beavatkozó és mentő szervezet felállítása (vezetés, irányítási rend, felelősségi szabályok, stb.)

- Hozzáférés biztosítása a kárelhárítási berendezésekhez és védelmi rendszerekhez.

- Riasztási, tájékoztatási és baleset-megelözési terv készítése (ha szükséges).

- Veszélyhelyzeti kommunikációs eszközök biztosítása.

- Lokalizációs eszközök biztosítása a vizek szennyezésének megelözésére, valamint az üzemi csatornák káros anyagok elleni védelmére.

- A kárelhárítási müszaki eszközök rendelkezésre állásának ellenőrzése, mint például szivattyúk és gyüjtőtartályok, mobil gyüjtőedények, és/vagy tömítő anyagok (aknák és csatornák nyílásainak lefedése, folyadék terelőgátak telepítése).

- A külső felfogó létesítményekkel, illetve a szennyezett oltóvíz folyamatos eltávolításával kapcsolatos kérdések tisztázása.

- Megállapodás a szennyvíztisztítóval a szennyezett oltóvíz ártalmatlanításának kérdésében. [9]
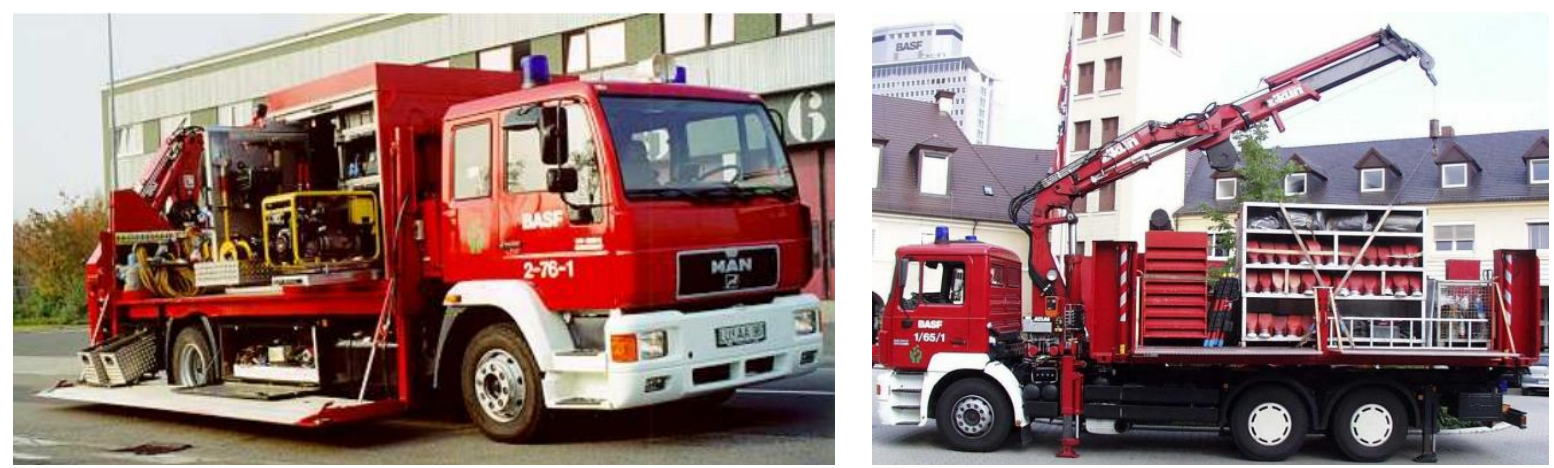

3. fénykép: Létesítményi tűzoltóság vízszennyezési gépjárművei BASF [10]

A szennyezett oltóvíz felfogására szolgáló műszaki intézkedések:

Az oltóvíz felfogásához előnyben kell részesíteni az önmüködö, beépített szerkezetü rendszereket, amelyek a rendeltetésüknek megfelelően és vízzáró módon a felfogott oltóvíz mennyiséget biztosítják kiegészítő intézkedések nélkül. Eredményesebb lehet a központi telephelyi oltóvíztároló, mint az oltóvíz helyi (épületben, vagy a tüz keletkezési helyénél történő) felfogása. Müszaki intézkedések lehetnek például:

- A tárolóépülethez külön oltóvíz felfogó medence alkalmazása szivattyú nélkül csatlakoztatva. Különösen veszélyes területek (például a horganyozó berendezéseket, vegyszertároló létesítményeket) védelmére közvetlenül kármentőhöz kell létesíteni a megfelelő méretü felfogó medencét.

- Az oltóvíz felfogására szolgáló terek végső ellenőrző aknáit tűzálló kivitelben kell megépíteni.

- Kerülni kell az oltóvíz felfogására szolgáló területen a belső esővíz lefolyó csöveket. Ezeket úgy kell megtervezni, hogy legalább a várható vízállás magasságáig tüzállók legyenek.

- Az épületek tárolótereinek felfogó medenceként történő kiépítése (felhajtók, ajtóküszöbök, rámpák és keresztező esővízcsatornák).

- Felszín alatti felfogó aknák építése a szennyezett oltóvíz tárolás céljából.

- Megfelelő méretü felfogó (puffer) medencék telepítése a telephelyi szennyvíztisztító telepen, illetve a csapadékvíz gyüjtő medencék alkalmazása. 
- Vízzáró nyitott tároló területek és lejtős elfolyási felületek, amelyek esetében az oltóvíznek vészelzáró szerkezettel ellátott gyüjtőmedencébe (vagy aknába) kell lefolynia.

- A meglévő vészelzáró szerkezetekkel ellátott szennyvízvezeték csatorna egyes részeinek használata az oltóvíz elvezetéséhez.

- Oltóvíz tartályok telepítése. A feltöltő szivattyúkat úgy kell méretezni, hogy biztosítsák a szükséges kapacitást, amelyet üzempróbával kell ellenőrizni.

- Mobil gyüjtőedények és tálcák alkalmazása.

- A lefolyókat tüzálló kivitelben kell megtervezni.

- Különféle felfogó eszközök alkalmazása: lefolyó beömlőnyílások fedelei; fedelek és tömítő párnák (vízzel vagy homokkal feltöltve); mágneses fólia; felfújható tömítő párnák (például csatornalefolyó beömlő nyílásokhoz); telepíthető gyüjtőedények (összehajtható tartály, konténer, stb.) többcellás tömlők folyadékfelfogáshoz. [9]

A telepíthető oltóvíz gátak használatánál biztosítani kell, hogy a mobil eszközök telepítése időben történjen, illetve gondoskodni kell azok üzembiztos müködőképességéről a személyzet képzésével és a szükséges müszaki berendezések rendelkezésre bocsátásával.

A gyártó és tároló üzemi területeken oltóvizet felfogó létesítményeknél előnyben kell részesíteni a létesítmények kültéri telepítését. Lehet egy központi gyüjtőmedencét építeni egyazon épületben vagy különálló épületekben lévő több tüzszakaszhoz.

Az oltóvíz felfogók befogadó képességét úgy kell méretezni, hogy megfeleljen az adott tüzszakasz adottságaihoz, amelynél ki kell számítani a szükséges oltóvíz legnagyobb felfogott mennyiségét.

A felfogott oltóvíz szükséges mennyisége alapján a vízgyüjtő medence területet, a szükséges folyadékszint magasságot és a felfogó gátak számított magasságát is meghatározhatjuk. Ahol lehetséges, az átjáróknál a rámpákat úgy kell kialakítani, hogy az oltóvíz mennyiségének felfogását is biztosítsák.

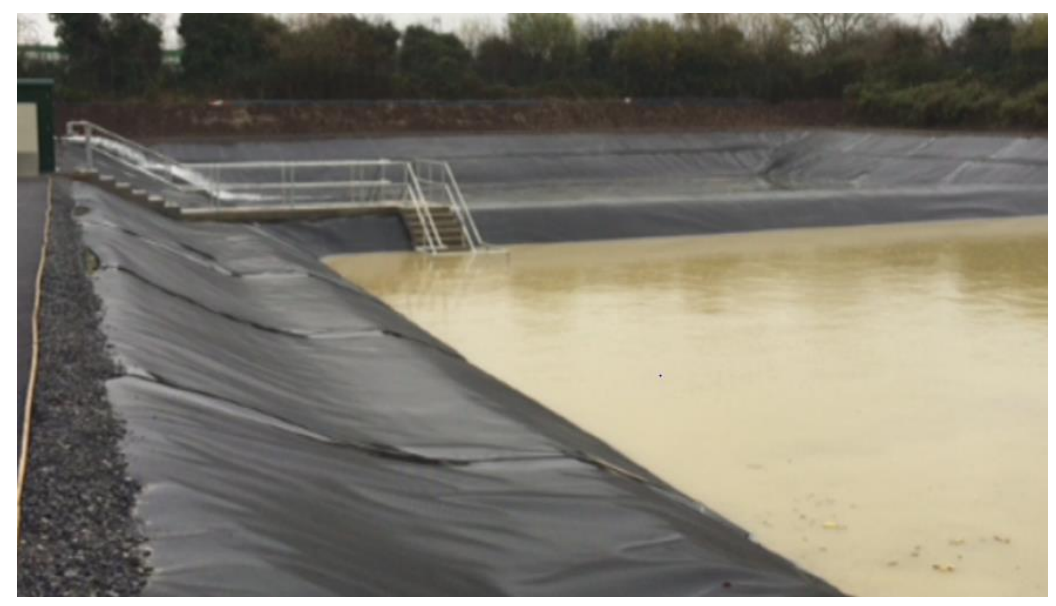

4. fénykép: Oltóvíz felfogó tároló létesítmény [11]

\section{AZ OLTÓVÍZ FELFOGÓ LÉTESÍTMÉNYEKKEL SZEMBEN TÁMASZTOTT KÖVETELMÉNYEK ÉRTÉKELÉSE}

Az oltóvíz felfogási intézkedéseket a belső védelmi terv vízminőségi kárelhárítási részében is rögzíteni kell. A megfelelően képzett kezelöszemélyzet feladatait a biztonsági irányítási rendszer keretében alkalmazott utasítás részeként elöre meg kell határozni. 
Az oltóvíz szennyezési (vízminőség kárelhárítási) elöírásoknak ki kell terjednie a következő fö elemekre:

- A felfogó müszaki berendezések leírása (méretek, szerkezeti kialakítás), beleértve az összes szerkezeti elemet (tolózárak, szivattyúk, csappantyúk stb.).

- A tüz esetén felfogandó maximális folyadék mennyiség meghatározása (oltóvíz, szennyvíz, kondenzvíz más üzemi területekről, kibocsátott veszélyes anyagok).

- A tüzoltó egységek épületen belüli mozgását segíteni kell. Az épületekben ahol az oltóvizet felfogják, a vízszintnek nem szabad túllépni a $30 \mathrm{~cm}$ maximális értéket. Kivétel csak a hatósággal és a tüzoltósággal történt egyeztetés alapján lehetséges.

- A befogadó csatornák esetében be kell mutatni, hogy a szennyezett oltóvíz mennyiség lefolyása a központi felfogó medencébe biztosított.

- Csatornázási terv, amelynek alapján bizonyítani kell, hogy a szennyezett oltóvíz a tüz további terjedését nem okozza.

- Az oltóvíz befogadásához szükséges biztonsági berendezések leírása (a vezérlés típusa, kezelhetősége, tápellátása, meghibásodás esetén követendő eljárás, a müködőképesség automatikus ellenőrzése).

- Az eredményes oltóvíz felfogáshoz szükséges belső intézkedési terv. Biztonsági szabály lehet a következő: nem szabad veszélyeztetni a kezelöket az oltóvíz felfogó létesítmények üzemeltetésének véletlenszerü megkezdésével, vagy ki kell zárni az automatikus indítás előzetes figyelmeztető jelzés nélkül lehetőségét. [9]

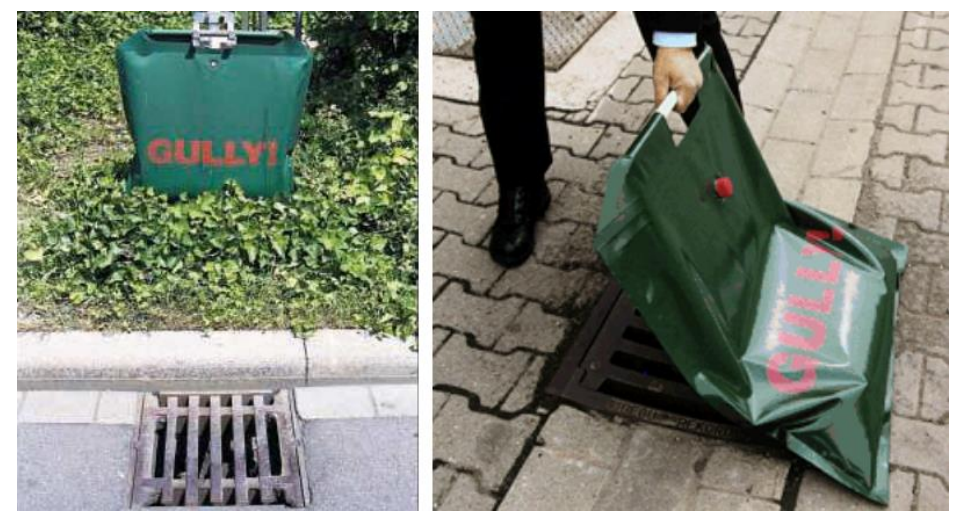

5. fénykép: Mobil akadály csatorna nyíláshoz [11]

Az oltóvizet felfogó létesítményeket úgy kell megtervezni, hogy ellenálljanak a szennyezett oltóvíznek, és vízzárók legyenek. Az oltóvizet felfogó létesítmények elemeinek tüzállónak kell lenniük. Emellett kellően teherbírónak és ellenállónak kell lenniük a tüz esetén felmerülő többi fizikai és vegyi hatásokkal szemben.

A létesítmények épületszerkezetét úgy kell méretezni, hogy megfeleljenek a rájuk nehezedő erőhatásoknak. Minden $10 \mathrm{~cm}$-es vízszint esetén további $\mathrm{kb} .1 \mathrm{kN} / \mathrm{m}^{2}$ felületi nyomás hat a padlóra. A felfogott oltóvíz tervezett vízállás magasságától függően számításba kell venni a falakra ható oldalirányú erőhatásokat is. Az oltóvizet felfogó létesítményeknek és a tömítő anyagoknak vízzárónak kell lenniük a tűz hőterhelése esetén is, és bírnia kell a beömlő oltóvíz nyomását. Ugyanez érvényes a felfogó berendezésen átvezetett csővezetékekre és kábelekre.

Müködési megbízhatóság szempontjaira tekintettel biztosítani kell, hogy a központi vezérlésű rendszereket még áramszünet esetén is el lehessen zárni. Két független tápforrás indokolt az automatikus vezérlésű rendszerek tápellátásának biztosítására. Önálló működtetésü rendszerek használata esetén, amelyek például pneumatikusan, hidraulikusan vagy gravitációs erővel müködnek, a második, független energiaforrás elhagyható. A kézi indítású rendszerek telepítését és indítását 60 másodpercen belül kell rendelkezésre bocsátani. 
A felfogó létesítményeket a tüz érzékelésekor, és a tüzoltás megkezdése előtt kell beüzemelni. Minden elemet úgy kell megtervezni, hogy kizárja a meghibásodás lehetőségét. Ki lehet alakítani a már meglévő tüzvédelmi rendszerekhez (például füst- és hő elvezető, szellőztető rendszerekhez, tüzérzékelő és tüzjelző rendszerekhez és tüzoltó rendszerekhez) történő kapcsolódást is.

A szennyezett oltóvíz felfogó eszközök biztonságos kezelése érdekében az automatikus müködtetésủ rendszereket úgy kell megtervezni, hogy kizárja a téves riasztások lehetőségét. Biztosítani kell, hogy azok üzemképességét egyértelműen ellenőrizni lehessen. Továbbá ki kell zárni a nem tervezett leállásukat.

A telepíthető mobil gátak esetén rendelkezésre kell állni megfelelő kezelő személyzetnek. A gátak méretének és súlyának olyannak kell lennie, hogy ezeket legfeljebb 2 kezelő önállóan képes legyen telepíteni.
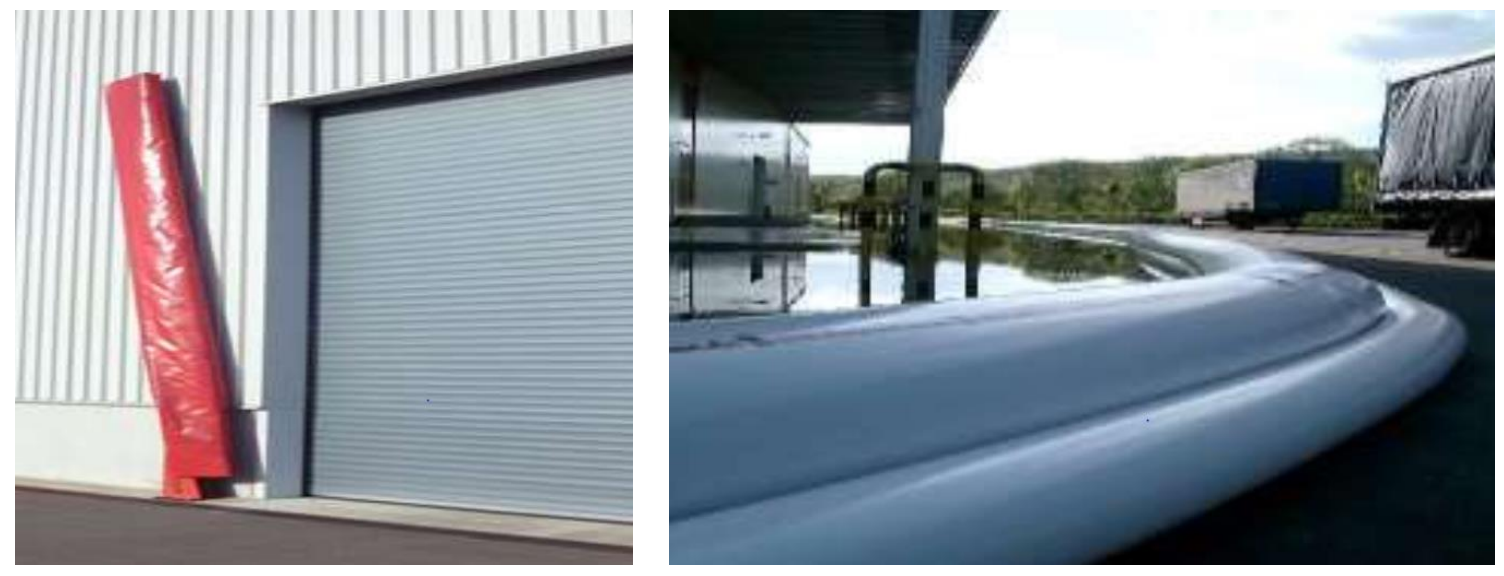

6. fénykép: Lengő mobil gát bejárathoz és kettős gumitömlő mobil rendszer [11]

Amennyiben az oltóvíz tüzveszélyes folyadékokkal keveredhet, vagy ha tüz esetén éghető gáz szabadulhat fel, akkor be kell tartani a robbanásvédelmi elöírásokat és az elektrosztatikus feltöltődés elleni védelemmel szemben támasztott követelményeket.

A szennyezett oltóvíz felfogó létesítmények kialakítási szabályai a következők:

- Az oltóvíz gátakat az átjárókban és kapubejáratokban úgy kell bent telepíteni, hogy a kapuk és ajtók nyithatók maradjanak tüz esetén.

- Az épület oltóvíz felfogására használt padlóit, határoló falait, nyílásait, átvezetéseit vízzáróság, mechanikai sérülések és tűzállóság szempontjából ellenőrizni kell. A kézi telepítésű eszközöket a bejárat közelében kell elhelyezni, vagy ha a kezelőszemélyzet nem áll rendelkezésre, akkor a rendeltetési helyére kell telepíteni. A gátakat védett helyen kell tartani és megóvni a külső behatásoktól.

- Bizonyítani kell a meglévő oltóvíz felfogó térbe történő elvezetésére szánt csővezetékek és szennyvízcsatorna rendszerek víztömörségét és üzemi szentvízrendszertől való zárhatóságát. Az üzemi szennyvíz megfelelő teljesítményü levezetését ilyen esetében is biztosítani kell. A csővezeték vagy szennyvízvezeték befolyó nyílását az eldugulástól meg kell óvni merülő csövek vagy durva szürős beömlő nyílások alkalmazásával. Gondoskodni kell a tüzveszélyes anyaggal kevert oltóvíz levezetésére alkalmazott csővezeték robbanás elleni védelmét.

- A szennyezett oltóvíz lefolyóiba szerelt elzáró szerelvényeket zárt állásban kell tartani. Az elzáró szerelvénynek automatikusan kell nyílnia, vagy kézi nyithatóságát biztosítani kell. A földalatti csövek elzáró szerelvényeit jelzésekkel kell ellátni. A bontható kötéseket és szerelvényeket felügyelet alatt álló, rendszeresen ellenőrzött csatornákban kell elhelyezni. 
- A beépített vagy mobil szennyezett vízszállító szivattyúk müködőképességét (tápellátását) folyamatosan és tüz esetén is biztosítani kell. A szennyezett oltóvíz tároló létesítményt folyadék túltöltés elleni védelemmel kell ellátni.

- A szennyezett oltóvizet a gyártási és tárolási területeken kívül eső medencékbe vagy tartályokba szükséges elvezetni. Indokolt oltóvíz gátakat használni a tüzveszélyes folyadékok esetében.

- Az oltóvíznek nem szabad átjutnia a szomszédos tüzszakaszokba, kivéve, ha ezeket az oltóvíz felfogására tervezték. A veszélyes anyagok kibocsátása esetén használt kármentőket az oltóvíz és hab megfelelő mennyiségü befogadására is alkalmassá kell tenni. Az útmutató szerint ezeknél rendszerint $30 \mathrm{~cm}$-rel nagyobb magasság kell az oltóvíz felfogására, továbbá túltöltés elleni védelemmel is el kell látni. A vízzel nem keveredő tüzveszélyes anyagok kármentőit beépített habbal oltó rendszerrel kell felszerelni.

- Az oltóvíz felfogására szolgáló telepített és mobil tartályok tüzvédelméről (például szellőzéséről, robbanásvédelméről, gázvédelméről) gondoskodni kell. [9]

\section{KÖVETKEZTETÉSEK}

Vizsgálataink alapján az alábbi következtetések fogalmazhatók meg:

1. 2013-évben a Német Biztosítók Szövetsége által kiadott VdS 2557. számú az „oltóvíz felfogó létesitmények tervezéséröl és kivitelezéséröl szóló útmutató” eleget tesz az ENSZ EGB Útmutató tervezetben megfogalmazott követelményeknek és kiváló például szolgálhat a szervezési és müszaki intézkedések meghatározása tekintetében.

2. Az oltóvíz okozta károk elkerülését célzó intézkedések szükségességét, fajtáját és mértékét az útmutatóban lévő részletes veszély- és kockázatelemzésre alapozva kaphatjuk meg. A számítások alkalmazásához mintapéldákat ad az útmutató, továbbá internetes alkalmazás szolgál segítségül a tervezö szakembereknek. Mindazonáltal a tervezés véleményem szerint megfelelő mérnöki és müszaki szakértelem és képzettség nélkül viszonylag nehézkes lehet.

3. Az útmutató tartalmazza továbbá a tűz során keletkezett oltóvíz mennyiségének számítását, a szennyezett oltóvíz által okozott károk elkerülése és kezelése céljából alkalmazandó szervezési intézkedéseket, az oltóvíz felfogásához szükséges müszaki intézkedéseket, az oltóvíz felfogására szolgáló létesítmények építésére, telepítésére, valamint felülvizsgálatára, karbantartására és üzemeltetésére vonatkozó követelményeket, a káreseménynél szükséges teendőket, a szennyezett oltóvíz ártalmatlanítására vonatkozó elöírásokat. Számításba kell venni, hogy a tüzoltóság beavatkozása nagy mennyiségü szennyezett oltóvizet képezhet. Ezt többek között a vizet veszélyeztető mủanyag alapú vegyületek használata okozza.

4. Az útmutató esettanulmányokon keresztül igazolja, hogy az oltóvíz szennyezettségét nemcsak a jelen lévő veszélyes anyag okozhatja, hanem az épületszerkezet, a termelési és csomagoló anyagok, valamit a tüz során keletkező égéstermékek is, ezért a veszélyeztetés előfordulhat súlyos baleseti szempontból nem azonosított telephelyek esetében is.

5. Hasonló veszélyeztetéssel lehet a felhasznált oltóhab vízi környezetre veszélyes habképző anyaga is, amely PFOS (perfluoroktán-szulfonát), PFA (perfluoralkoxi) összetevőket tartalmaz.

6. Az oltóvíz által okozott kár kizárólag tüzesemény bekövetkezése után várható nagy mennyiségü szennyezett oltóvíz kibocsátásával együtt. Ezért az oltóvíz felfogása nem szükséges, ha a tüz lehetősége egyértelmüen kizárható, vagy ha az esetlegesen bekövetkező tüzet nem vízzel oltják, továbbá ha az anyag kockázati potenciáljának az útmutató szerinti veszély- és kockázatelemzési eredménye zömmel "alacsony" és csak részben "közepes" értéket mutat. 
7. Megállapítható továbbá, hogy a veszélyes anyag raktárak és termelő üzemek megkülönböztetése nem indokolt, mivel az oltóvíz által okozott károk mindkét esetben egyaránt kialakulhatnak.

8. Vizsgálataink alapján megállapítható, hogy Európa szerte jelentős azon korszerü raktárak száma, ahol már figyelembe veszik a felszíni és felszín alatti vizek szennyezett oltóvízzel történő szennyezés megelőzési irányelveket. Azonban a meglévő raktárak és üzemek vonatkozásában az általunk vizsgált szakkérdésben még elmaradások mutatkoznak.

9. A súlyos balesetek és jelentős tüzesetekkel járó esetleges környezetszennyezések elhárítása részét kell, hogy képezze a hazai katasztrófavédelmi felsőoktatásnak, valamint a létesítés alatt lévő tüzvédelmi mérnöki alapképzésnek [12]. Utóbbi megvalósításához természettudományi, müszaki alapozó ismeretek, vízgazdálkodási és környezeti kárelhárítási ismeretek oktatására is szükség van.

\section{FELHASZNÁLT IRODALOM}

[1] Ivan Vince: Major accidents to the environment: a practical guide to the Seveso II directive and COMAH regulations. Oxford. Elsevier 2008. ISBN 978-0-85293-437-1.

[2] EAWAG. Rhine running red, fish dead - 30th anniversary of the Sandoz blaze.

URL.: http://www.eawag.ch/en/news-agenda/news-portal/news-archive/archive-detail/ news/der-rhein-rot-die-fische-tot-30-jahre-nach-dem-sandoz-brand/ (letöltés: 2018.03.15)

[3] UN Economic Commission for Europe. UNECE prepares guidance on fire-water retention to avoid another Sandoz accident, Genf, 2017.

URL.: https://www.unece.org/info/media/presscurrent-press-h/environment/2017/uneceprepares-guidance-on-fire-water-retention-to-avoid-another-sandoz-accident/doc.html. (letöltés: 2017.12.25)

[4] UN Economic Commission for Europe. Convention on Transboundary Effects of Industrial Accidents, done at Helsinki, on 17 March 1992.

[5] UN Economic Commission for Europe. Convention on the Protection and Use of Transboundary Watercourses and International lakes done at Helsinki, on 17 March 1992. (Helsinki Határvízi Egyezmény)

[6] UN Economic Commission for Europe. Draft UNECE Safety Guidelines and Good Practices for Fire-water Retention. Genf, 2017. http://www.unece.org/fileadmin/DAM/env/documents/2017/TEIA/JEG_MTGS/UNEC E_Safety_Guidelines_and_Good_Practices_for_Firewater_Retention_14_Nov_2017_clean.pdf (letöltés: 2017.12.25)

[7] 2012/18/EU (Seveso III.) Irányelv az Európai Parlament és a Tanács a veszélyes anyagokkal kapcsolatos súlyos balesetek veszélyének kezeléséröl, valamint a 96/82/EK tanácsi irányelv módosításáról és későbbi hatályon kívül helyezéséről

[8] CIMER Zsolt, SZAKÁL Béla, HOFFMANN Imre: Compliance with the new legal requirements on the demonstration of safety management systems in the safety report. SCIENCE FOR POPULATION PROTECTION 8:(2) pp. 1-12. (2016)

[9] VdS 2557 VdS Schadenverhütung GmbH., Planning and Installation of Facilities for Retention of Extinguishing Water. Guidelines for Loss Prevention by the German Insurers, No. VdS 2557, Koln, Germany, 2013. URL.: https://vds.de/fileadmin/vds_publikationen/vds_2557en_web.pdf. (letöltés: 2018.01.20) 
[10] Gerhard Zimmer. Prevention of industrial accidents. In.: UNECE Seminar Sandoz 25+ 8 - 9 November 2011, Bonn, Németország. URL.:

http://www.unece.org/fileadmin/DAM/env/teia/doc/Sandoz/08_Cefic_Zimmer_Eng.pdf (letöltés: 2018.03.20)

[11] JMM. Fire water retention facility. URL.:http://jackiemcmahonconstruction.com/firewater-retention-facility/ (letöltés: 2018.03.20)

[12] Vass Gyula: A katasztrófavédelmi képzés helyzete a rendészeti felsőoktatás rendszerében. In: Dobák Imre, Hautzinger Zoltán (szerk.) Szakmaiság, szerénység, szorgalom: Ünnepi kötet a 65 éves Boda József tiszteletére. 674 p. Budapest: Dialóg Campus Kiadó; Nordex Kft., 2018. pp. 659-667. (ISBN:978-615-5889-51-6) 